\title{
Conservative and esthetic approach in crown fracture of maxillay anterior tooth: tooth fragment reattachment
}

\author{
Kyoung-Hwa Jung ${ }^{1,2}$, Eun-Young Kwon', So-Yeun Kim¹, Hye-Mi Jeon', Sung-Ae Son², Jeong-Kil Park ${ }^{2 *}$ \\ 'Dental Clinic Center, Pusan National University Hospital, Busan, Republic of Korea \\ ${ }^{2}$ Department of Conservative Dentistry, School of Dentistry, Pusan University, Yangsan, Republic of Korea
}

Crown fractures are the most frequent traumatic injuries to permanent teeth and mainly involve the maxillary incisors due to their exposed position in the dental arch. One option for managing crown fractures, when the tooth fragment is present and in good condition, is reattachment of the fragment to its original position. This paper reports on three crown fracture cases in which successful esthetic and functional results were achieved by reattachment of the tooth fragment. (J Dent Rehabil Appl Sci 2019;35(2):105-12)

Key words: crown fracture; tooth fragment reattachment; esthetic approach; conservative approach

\begin{abstract}
서론
치관 파절은 영구치에서 가장 많이 발생하는 외상성 손상이며 교통사고, 운동, 가정에서 발생하는 예기치 않 은 사고 등이 전치부 치관 파절의 주요 원인이다. ${ }^{1}$ 치열 에서 가장 노출된 위치에 존재하는 특성으로 인해 상악 전치에서 치관 파절이 가장 많이 발생하며, 이 부위에 발 생한 치관 파절은 심미적, 기능적, 발음적 문제를 일으킨 다. ${ }^{2}$
\end{abstract}

치관 파절의 치료 방법은 파절편 재부착(tooth fragment reattachment), 복합레진을 이용한 수복, 전장관 수 복 등으로 다양하다. 수복 방법을 선택하는데 있어서는 환자의 나이, 잔존 치질의 양과 질, 파절의 정도, 치아 맹 출과 치근 형성의 정도, 교합 관계, 심미적 기대, 치수와 치주 조직의 포함 여부 등과 같은 다양한 요소들을 고려 해야 한다. ${ }^{3}$

1955년 Buonocore ${ }^{4}$ 에 의해 산부식(acid-etching) 술식

*Correspondence to: Jeong-Kil Park

Professor, Department of Conservative Dentistry, Pusan National University 20, Geumo-ro, Mulgeum-eup, Yangsan, 50612, Republic of Korea

Tel: +82-55-360-5221, Fax: +82-55-360-5214, E-mail: jeongkil@pusan.ac.kr

Received: February 11, 2019/Last Revision: March 8, 2019/Accepted: April 25, 2019
이 소개된 이후부터 복합레진을 이용한 수복 술식과 파 절편 재부착 술식을 이용할 수 있게 되었고, 이로 인해 파 절치의 치료는 건전 치질을 더 보존하는 방향으로 발전 할 수 있게 되었다. 치아 파절편이 존재하고 오염이 되어 있지 않으며 단일 파절편으로 존재하여 잔존 치질의 파 절면에 적절한 변연 적합을 보일 경우, 기존 파절편을 재 부착하는 술식은 보존적이고, 심미적이며 경제적인 측면 에서 복합레진 수복 및 크라운 수복에 비해 더 적절한 치 료적 대안이 되고 있다. ${ }^{5,6}$ 파절편 재부착 술식은 파절편 의 탈수로 인한 색조 변화와 관련하여 색조 조화를 이루 기 어려운 경우가 있을 수 있다는 점과 치아의 파절면에 재부착 시킨 파절편의 탈락 가능성과 같은 단점도 존재 하지만, ${ }^{5}$ 기존 치아를 사용함으로써 치아가 가지고 있던 원래의 해부학적 형태와 색상, 배열, 표면 질감이 유지된 다는 점에서 장기간에 걸친 좋은 심미적인 결과를 보이 며, ${ }^{7}$ 복합레진 수복을 시행하는 경우에 비해 술식 시간의 절약, 마모 안정성의 획득 측면에서 더 나은 결과를 보였

CopyrightC 2019 The Korean Academy of Stomatognathic Function and Occlusion. (c) It is identical to Creative Commons Non-Commercial License. 
다. ${ }^{3}$ 또한, 전장관 수복에 비해 불필요한 치질 삭제가 없 다는 점이 장점이 된다.

파절편 재부착의 높은 성공률을 보고하는 문헌들이 다 양하게 존재함에도 불구하고 수많은 임상가들은 여전히 발치, 임플란트 시술, 전장관 수복과 같은 보철적인 술식 을 선택하고 있다. 이는 아마도 파절편 재부착 술식에 대 한 지식 부족이나 실패에 대한 두려움 때문일 것이다. ${ }^{8}$

따라서, 이번 증례보고에서는 상악 전치부 치관 파절에 대해 보존적이고 심미적인 치료 결과를 얻은 파절편 재부 착 술식 증례와 술식 시 고려할 사항에 대해 보고하고자 한다.

\section{증례보고}

\section{증례 $A$}

새벽에 넘어져서 앞니를 다쳤다는 주소로 19세 여자 환자가 내원하였다. 임상 검사 및 방사선 검사 결과 상악 우측중절치 치관의 중간 $1 / 3$ 지점에서 사선 형태의 치관 파절이 발생하였고 원심측 치수각에서 치수가 노출된 것 을 확인할 수 있었다. 병원에 내원하기까지 파절편은 약 2 - 3시간의 시간 동안 우유에 보관된 상태였다(Fig. 1A, $1 \mathrm{C})$. 파절편 검사 결과 파절편은 절단면 일부만 손상되어 사라진 상태였으나 파절면과의 적절한 변연 적합이 확인 되었으므로 우선 파절편 재부착 후 절단면 일부 결함 부 위는 추가적인 복합레진 수복 술식을 시행하기로 결정하 였다.

파절편 재부착에 앞서, 파절편은 탈수를 막기 위해 생 리식염수에 30 분 동안 보관하였다. 노출된 치수에 대 해 치수복조술을 시행하기 위해 국소마취를 먼저 시행
한 후 생리식염수와 클로르헥시딘(chlorhexidine) 용액 으로 조심스럽게 세척을 하고 노출된 치수 부위에 소독 된 면구를 이용하여 눌러줌으로써 지혈을 시행하였다. 지 혈이 완료된 후 수산화칼슘(calcium hydroxide) 제재인 Dycal (Dentsply Caulk, Milford, USA)을 적용하고 경 화되기를 기다리는 동안 파절편의 치수 부위를 삭제하 여 차후 복합레진이 들어갈 부가적인 공간을 마련하였 다. 파절편과 파절면의 법랑질 부위에 30 초 동안 $35 \%$ 인 산(Ultra-Etch, Ultradent Products, Inc, South Jordan, $\mathrm{USA}$ )을 적용한 후 30 초간 수세 및 건조하였다. 그 후 접 착제(Scotchbond Multipurpose Adhesive, 3M ESPE, St Paul, USA)를 파절면, 파절편 조각에 얇게 적용한 후 광 중합기(Demi LED Light Curing System, 450nm, Kerr, USA)를 이용하여 중합을 시행하였다. 치아 파절면과 치 수 삭제를 통해 마련해둔 파절편의 부가적인 공간을 포 함한 파절편의 파절면 전체에 복합레진(Tetric $\mathrm{N}$ flow A2 shade, Ivoclar Vivadent, Schaan, Liechtenstein)을 적 용한 후 파절편을 치아 파절면에 적절히 위치시켰다. 잉 여의 복합레진을 제거한 후 순면, 구개면에서 차례로 광 중합을 하고 교합 조정을 시행하였다(Fig. 1B). 1주일 후 에 시행한 임상 검사 및 방사선 검사 결과, 치관 변색 소 견은 관찰되지 않았고 양호한 심미적 상태가 유지되었 다. 환자는 통증 및 불편감을 호소하지 않았으며 냉검사 및 전기치수검사에 양성 반응을 보였고, 타진에 대한 반 응이 없었으며 치근단 부위의 이상 소견도 관찰되지 않 았다. 초진 시 존재했던 파절편의 절단연 결함 부위는 직 접 복합레진 수복을 시행하여 회복하였다(Fig. 2A). 그 후 30 개월 간의 추적 관찰 동안 치아의 치수생활력은 유 지되었으며 수복된 치아의 심미적 문제도 발생하지 않았 다(Fig. 2B, 2C).
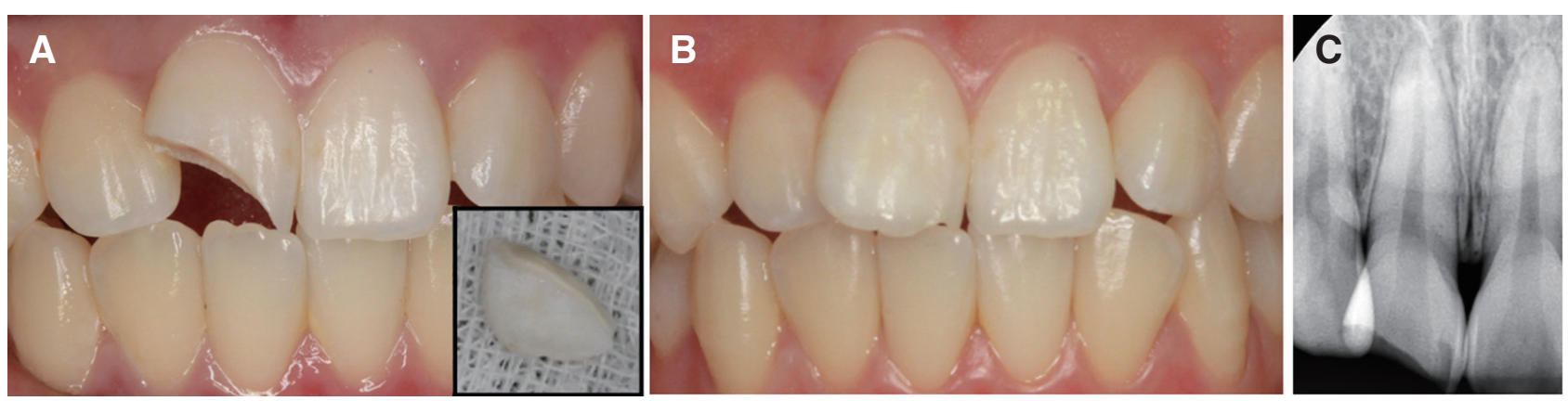

Fig. 1. Tooth fragment reattachment of Case A: (A) Preoperative photographic image of the fractured tooth and tooth fragment, (B) Immediate postoperative photographic image, (C) Preoperative radiographic image of the fractured tooth. 

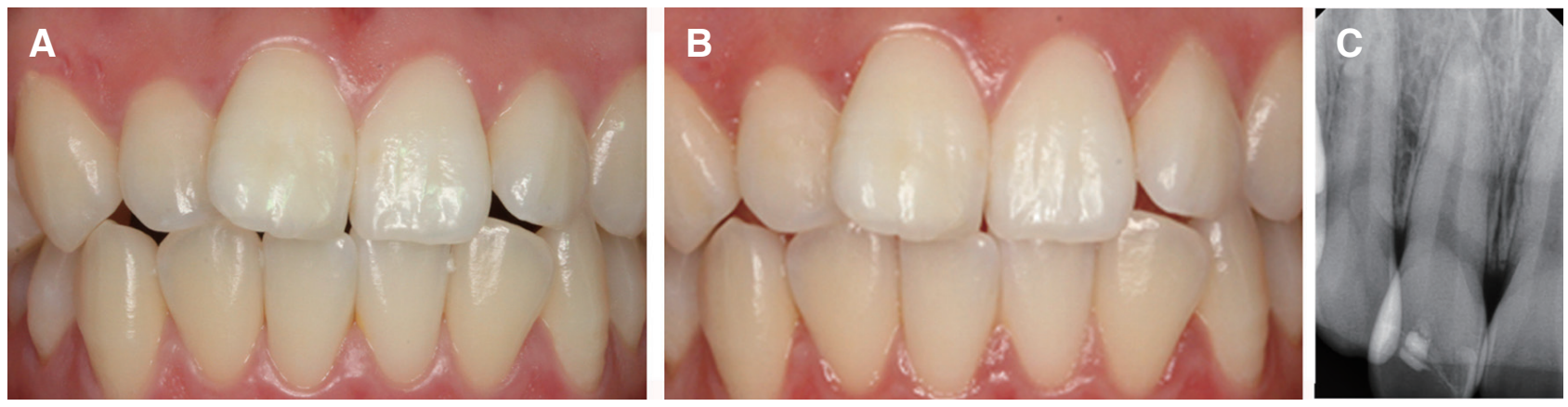

Fig. 2. Postoperative images of Case A: (A) 1 week follow-up. Resin restoration of the fractured incisal edge, (B) Photographic image at 30 months follow-up, (C) Radiographic image at 30 months follow-up.

\section{증례 B}

어젯밤 방에서 넘어져 앞니가 깨졌다는 주소로 24세 여자 환자가 내원하였다. 임상 검사 및 방사선 검사 결 과 상악우측중절치의 근, 원심 치수각을 포함한 일부 치 수노출을 동반한 치관 파절이 확인되었다. 넘어진 당시 파절편은 두 조각으로 나뉘어졌으며 종이에 싼 채 건조 된 상태로 보관된 상태였다(Fig. 3A, 3C). 파절편 확인 결 과, 두 조각의 파절편의 변연 적합 및 파절편과 치아 파절 면 사이의 변연 적합이 적절하였으며, 가능한 한 파절편 을 그대로 사용하기를 원하는 환자의 요구에 따라 파절 편 재부착을 시행해보기로 하였다. 수복 술식을 시행하 기에 앞서 파절편을 생리식염수에 1시간 보관하였다. 노 출된 치수에 대해서는 국소마취 하에 생리식염수와 클로 르헥시딘 을 이용한 세척 및 소독된 면구를 사용한 지혈 을 시행한 후 Dycal을 적용하였고, 파절편에 대해서는 치 수각 부위 치수 제거를 통해 부가적인 공간을 형성했다. 파절편과 치아 파절면 양측에 동일하게 30 초간 $35 \%$ 인
산 적용 및 수세, 건조 시행 후 접착제를 얇게 도포하고 광중합을 시행한 후에 치아 파절면과 치수 삭제를 통해 마련해둔 파절편의 부가적인 공간을 포함한 파절편의 파 절면 전체에 복합레진를 적용하고 파절편을 치아 파절면 에 적절히 위치시켰다. 잉여의 복합레진을 제거한 후 순 면, 구개면에서 차례로 광중합을 하고 교합 조정을 시행 하였다. 재부착 직후 확인 시 오랜 시간 건조한 상태에서 보관되었던 파절편 색조가 치아에 비해 더 밝아 보이는 상태임을 확인할 수 있었다(Fig. $3 \mathrm{~B}$ ). 주기적인 추적 검사 를 통해 시간이 지날수록 파절편의 색조가 안정되어 치 아의 색조와 조화를 이루는 것을 관찰할 수 있었지만, 12 개월 후 추적 검사 당시 두 조각 파절편으로 인해 형성된 파절선 부위의 색조 안정성이 떨어지는 것이 관찰되었고, 이를 해결하기 위해 파절편 사이 변색이 일어난 파절선 부위를 삭제하고 복합레진으로 수복을 시행하였다(Fig. $4 \mathrm{~A}$ ). 이후 34 개월 간의 추적 관찰 동안 치아의 치수생활 력이 유지되었으며 수복된 치아의 심미적 문제도 발생하 지 않았다(Fig. 4B, 4C).
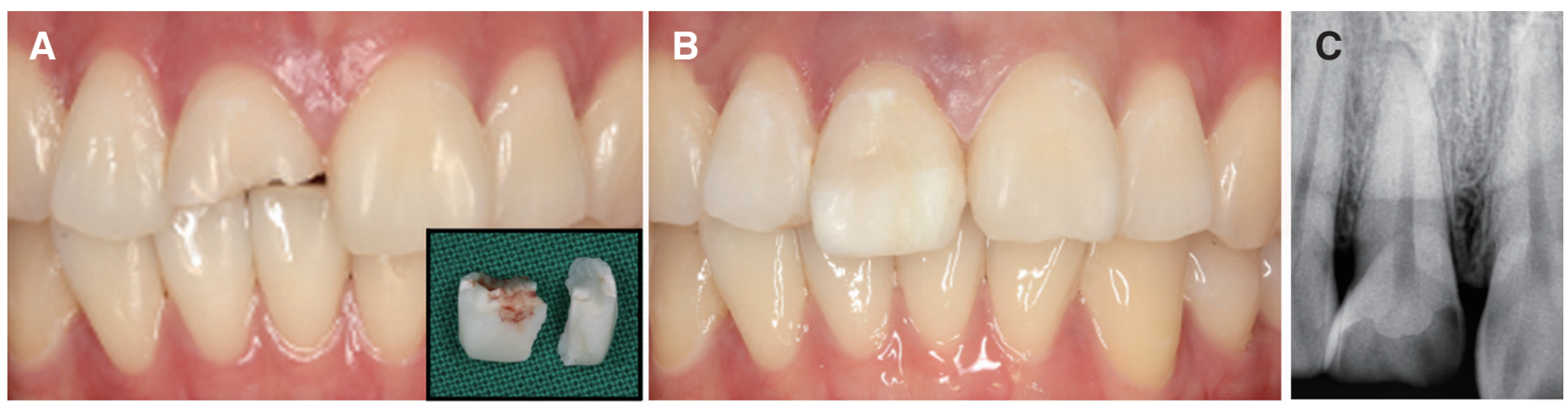

Fig. 3. Tooth fragment reattachment of Case B: (A) Preoperative photographic image of the fractured tooth and tooth fragments, (B) Immediate postoperative photographic image, (C) Preoperative radiographic image of the fractured tooth. 

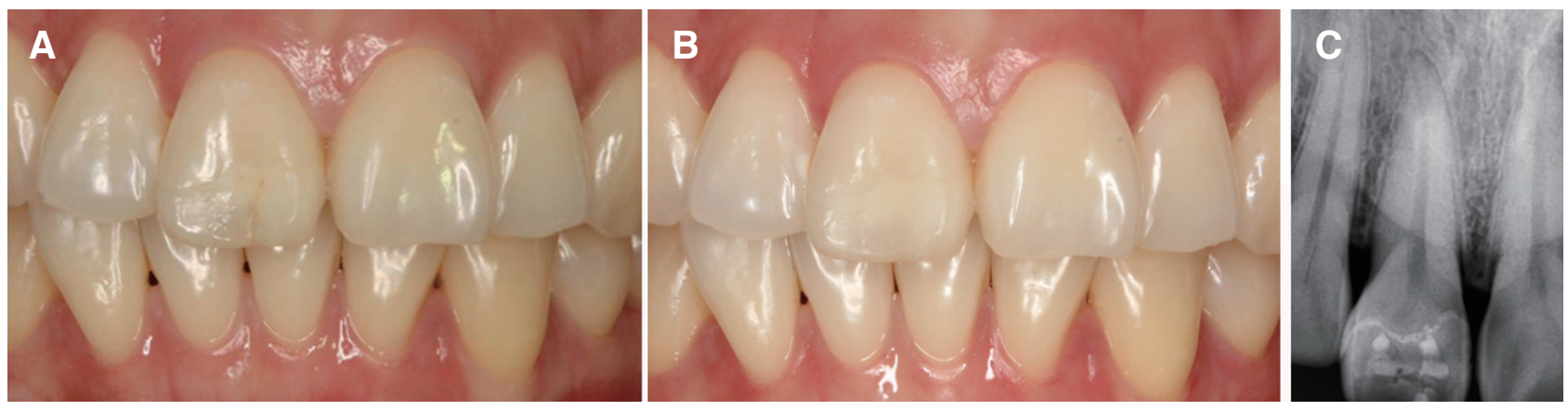

Fig. 4. Postoperative images of Case B: (A) 12 months follow-up. Discoloration on margin of fracture line, (B) Photographic image at 34 months follow-up, (C) Radiographic image at 34 months follow-up.

\section{증례 C}

2시간 전 장난감을 밟고 넘어져 앞니가 부러지고 흔들 린다는 것을 주소로 40 세 여자 환자가 내원하였다. 임상 검사 및 방사선검사 결과 상악우측중절치의 치근 파절 및 상악좌측중절치의 치수노출이 없는 치관 파절 및 치 아 아탈구로 진단하였다. 파절편 검사 결과 절단연의 원 심측 일부의 결함을 제외하고는 비교적 파절편 상태 양 호하였으며, 파절면과의 변연 적합도 또한 우수하여 파 절편 재부착 술식을 시행하기로 하였다(Fig. 5A, 5C). 30 분 이상 생리식염수에 담가 둔 파절편과 파절면 양측에 동일하게 30 초간 $35 \%$ 인산 적용 및 수세, 건조 시행 후 접착제를 얇게 도포하고 광중합을 시행하였다. 그 후 치 아 파절면과 치수 삭제를 통해 마련해둔 파절편의 부가 적인 공간을 포함한 파절편의 파절면 전체에 복합레진를
적용하고 파절편을 치아 파절면에 적절히 위치시켰다. 잉 여의 복합레진을 제거한 후 순면, 구개면에서 차례로 광 중합을 하고 교합 조정을 시행하고, 치근파절을 포함한 상악우측중절치 및 치아 아탈구를 동반한 상악좌측중 절치에 잠간고정술을 시행하였다(Fig. $5 \mathrm{~B}$ ). 이후 재내원 시 파절편과 파절치의 양호한 색조 조화는 보였지만(Fig. $6 \mathrm{~A})$, 상악좌측중절치의 치수생활력 검사 결과 치수괴사 확인되어 근관치료를 시행하기로 하였다. 설면 근관와동 형성 부위가 파절선과 떨어진 치경부측에 존재하였으므 로 파절선 하방으로 근관와동 입구를 형성하고 치아와 파절편 계면의 접착 부위를 삭제를 최소화하는 방향으로 근관와동을 형성하여 근관치료를 시행하였고, 절단연의 원심측 결함 부위는 직접 복합레진 수복을 통해 외형을 회복시켰다. 24 개월의 추적관찰 동안 파절편 재부착 부위 는 심미적으로 만족할 만한 결과를 보였다(Fig. 6B, 6C).
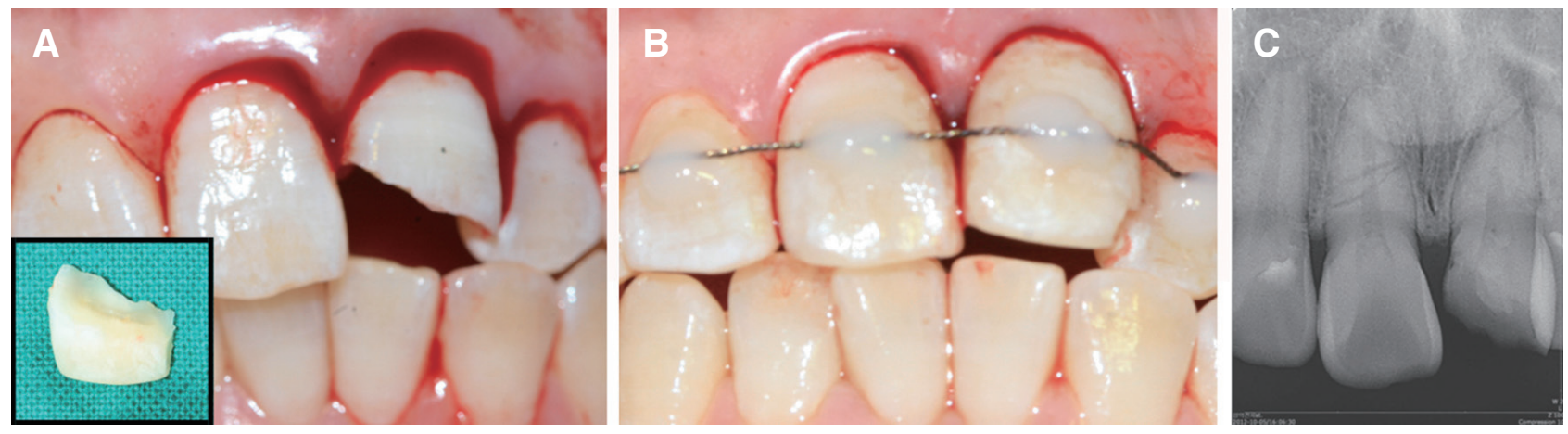

Fig. 5. Tooth fragment reattachment of Case C: (A) Preoperative photographic image of the fractured tooth and tooth fragment, (B) Immediate postoperative photographic image, (C) Preoperative radiographic image of the fractured tooth. 

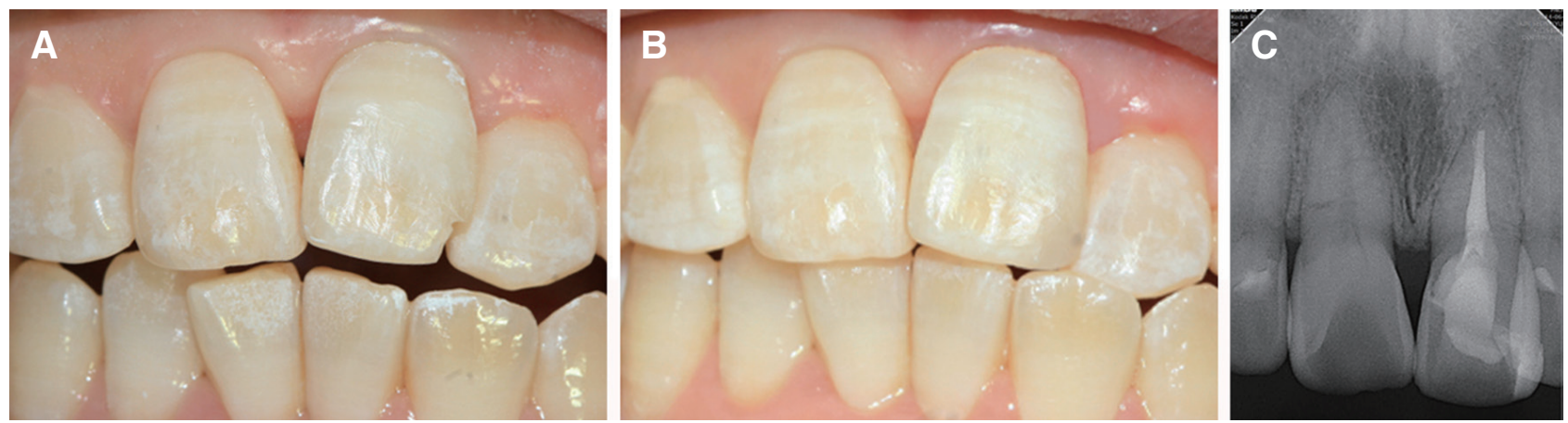

Fig. 6. Postoperative images of Case C: (A) 1 month follow-up, (B) Photographic image at 24 months follow-up, (C) Radiographic image at 24 months follow-up.

\section{고찰}

파절편의 원래 위치로의 재부착 술식은 치관 파절이 발 생한 치아에 대한 술식 중 가장 보존적인 접근법으로 생 각되고 있다. ${ }^{5,8}$ 직접 복합레진 수복으로 파절된 치아를 수복시키는 술식은 자연치의 색조, 투명도(translucency) 및 유백광 특성(opalescence), 형광성(fluorescence)과 같 은 광학적 특성 및 형태, 표면 질감을 완벽하게 재현하는 데 있어 상당한 기술이 요구된다. 따라서 파절면에 좋은 적합을 보이는 파절편이 존재하는 경우에는 심미적, 기 능적으로 훌륭한 회복을 제공하는 가장 빠르고 간단하 며 보존적인 치료 방법인 파절편 재부착 술식이 가장 좋 은 치료 방법이 될 수 있다.,

1964년 Chosak과 Eidelman ${ }^{10}$ 에 의해 파절편 재부착 술식이 처음 소개된 이후, 파절편의 기계적, 화학적 유지 력 향상을 위한 다양한 삭제(preparation) 방법(변연경 사(bevel), 샘펴(chamfer), 과풍융(overcontour), 상아질 내측 구(internal groove))과 접착제들이 여러 문헌들을 통해 소개되었다. ${ }^{11-14}$ Reis 등 ${ }^{11}$ 의 연구 결과에 의하면 파 절편 재부착 전에, 협측면에 샘퍼 형성, 과풍융, 내측 구 를 형성했을 때 건전한 치아의 파절 저항(fracture resistance) 값의 각각 $60.6 \%, 97.2 \%, 90.5 \%$ 수준의 회복이 일어나는 것이 확인되다. 하지만, 단순한 파절편 재부착 을 통해서도 파절 저항 값의 $37-50 \%$ 가 회복되는 것이 관찰되었다. ${ }^{11,12}$ 또한, 치아의 파절면에 대한 파절편의 결 합 강도에 대해서 궁극적인 역할을 하는 것은 접착제이 며, 추가적인 삭제 형성은 중요도가 떨어진다는 연구 결 과도 존재한다. ${ }^{13,14}$

이런 이유로 인해, 이번에 보고하는 증례에서는 파절편
상에 잔존하는 치수 조직을 제거함에 따라 형성된 상아 질 상의 내측 구 외에는 의도적인 추가 삭제를 시행하지 않는 것을 원칙으로 하였다. 증례 $\mathrm{B}$ 에서, 시간이 지남에 따라 두 조각의 파절편 사이 파절선 상의 색조 안정성에 있어 발생한 문제로 인해 추가적으로 시행한 파절선 부 위의 추가 삭제 및 수복을 통해 심미성 향상 뿐만 아니라 파절편 파절 저항의 향상도 추가적으로 가져왔을 것이라 생각된다. 또한, 치아 파절 외에 치아 아탈구도 동반되었 던 증례에서는 치수생활력의 상실로 인해 시행한 통상적 인 근관치료로 형성되었던 치수강 공간이 치아의 파절 저 항을 향상시키는 요소로 작용했을 것이라 생각된다.

파절편 재부착 술식 이후의 문제점 중 하나가 파절편 이 잔존 치아보다 좀 더 밝은 색조를 띠는 경우가 있다는 점이다. 이는 파절편 상아질의 건조로 인한 탈수와 콜라 겐 섬유의 파괴에 의해 발생한다. ${ }^{15}$ 따라서 파절편이 1 시 간 이상 건조된 상태로 보관되었을 경우, 색조 부조화를 피하기 위해 재부착 전 최소 30 분 동안 재수화(rehydration)시켜주어야 한다고 보고되었다. ${ }^{16}$ 완전한 재수화와 색조 조화가 일어나는데 까지는 통상적으로 1주일 이상 의 시간이 필요하지만 수 개월이 걸리는 경우도 있다고 하였다. ${ }^{17}$ 이번에 보고하는 증례에서 파절편을 2 - 3시간 동안 우유에 보관하다 가지고 내원한 증례와 외상 후 2 시간 후 바로 내원한 증례의 경우 상대적으로 파절편의 건조 시간이 짧아 30 분 정도의 재수화를 통해 색조 회복 이 적절히 일어났지만 하루 동안 건조 상태로 보관된 파 절편에 대해 1 시간의 재수화를 시행한 증례에서는 색조 회복이 적절히 일어나는데 시간이 상대적으로 많이 소요 되는 것을 확인할 수 있었다. Farik 등 ${ }^{18}$ 의 연구에 의하면 24시간 이상 탈수된 상태로 보관되었던 파절편이 필요로 
하는 최적의 재수화 시간은 탈수된 시간과 동일하거나 그 이상의 시간이라고 하였다. 이번 증례에서는 환자의 요구에 따라 내원 당일 파절편의 재부착을 시행하였지만 하루 정도 생리식염수 내에서 파절편 보관한 후 다음 날 파절편 재부착을 시행하였다면 색조 조화가 더 빨리 이 루어질 수 있었을 것으로 생각된다.

치관 파절 증례에서 치수가 노출되었을 경우에는 수복 치료에 앞서 치수 복조술, 치수 절단술과 같은 접근을 통 해 우선 치수생활력을 보존해야 한다. 치수 노출의 정도 가 크지 않은 경우 복합레진을 이용한 파절편 재부착 술 식 결과 파절에 대한 반응으로써 재생성 상아질이 형성 되는 경우가 종종 있으며 이 결과는 파절편 재부착 술식 이 치수의 기능을 유지시킬 수 있는 술식임을 의미한다. ${ }^{19}$ 이번에 소개한 증례 중 두 증례에서도 파절편 재부착 술 식 이후 장기간에 걸쳐 치수생활력이 유지되는 것을 확인 할 수 있었다. 이번 증례에서 치수 복조술에 사용한 수산 화칼슘 제재는 항균 능력이 뛰어나 세균의 침투를 제한 하여 치수 조직에의 자극을 최소화 해주며, 이 특성으로 인해 이번 증례에서 치수의 생활력이 유지되는데 역할을 했을 것으로 생각된다. ${ }^{20}$ 임상가는 파절편 재부착 시행 후에도, 주기적인 방사선 검사 및 임상 검사를 통해 치수 생활력 검사 및 파절편의 심미적, 기능적 문제 등에 대해 평가해야 하며 파절편의 탈락을 예방하기 위한 여러 습 관의 조절 및 주의 사항을 환자에게 고지해야 한다.

\section{결론}

치관 파절의 증례에서 접착 술식을 이용한 파절편 재부 착을 시행하는 것은 보존적, 심미적 측면에서 임상적으 로 만족할만한 결과를 보여주었다. 적절한 적합을 보여 주는 양호한 파절편이 존재하는 경우, 파절편의 재부착 술식은 치관 파절 증례의 가장 빠르고, 쉽고, 경제적이며 심미적, 기능적으로도 우수한 결과를 이룰 수 있는 술식 방법으로 우선적으로 고려되어야 한다.

\section{Acknowledgements}

본 연구는 2018년도 부산대학교병원 임상연구비 지원 으로 이루어졌음.

\section{ORCID}

Kyoung-Hwa Jung https://orcid.org/0000-0002-8305-0016

Eun-Young Kwon https://orcid.org/0000-0001-9555-0360

So-Yeun Kim http://orcid.org/0000-0001-6714-8315

Hye-Mi Jeon https://orcid.org/0000-0003-0007-5662

Sung-Ae Son https://orcid.org/0000-0002-8421-4000

Jeong-Kil Park https://orcid.org/0000-0001-6333-8138

\section{References}

1. Durkan RK, Ozel MB, Celik D, Bağiş B. The restoration of a maxillary central incisor fracture with the original crown fragment using a glass fiberreinforced post: a clinical report. Dent Traumatol 2008;24:e71-5.

2. Oz IA, Haytaç MC, Toroglu MS. Multidisciplinary approach to the rehabilitation of a crown-root fracture with original fragment for immediate esthetics: a case report with 4-year follow-up. Dent Traumatol 2006;22:48-52.

3. Baratieri LN, Monteiro S Jr, Caldeira de Andrada MA. Tooth fracture reattachment: case reports. Quintessence Int 1990;21:261-70.

4. Buonocore MG. A simple method of increasing the adhesion of acrylic filling materials to enamel surfaces. J Dent Res 1955;34:849-53.

5. Taguchi CM, Bernardon JK, Zimmermann G, Baratieri LN. Tooth fragment reattachment: a case report. Oper Dent 2015;40:227-34.

6. El-Askary FS, Ghalab OH, Eldemerdash FH, Ahmed OI, Fouad SA, Nagy MM. Reattachment of a severely traumatized maxillary central incisor, one-year clinical evaluation: a case report. J Adhes Dent 2006;8:343-9.

7. Reis A, Loguercio AD, Kraul A, Matson E. Reattachment of fractured teeth: a review of literature regarding techniques and materials. Oper Dent 2004;29:226-33.

8. Rajput A, Ataide I, Fernandes M. Uncomplicated crown fracture, complicated crown-root fracture, and horizontal root fracture simultaneously treated in a patient during emergency visit: a case report. Oral Surg Oral Med Oral Pathol Oral Radiol En- 
$\operatorname{dod} 2009 ; 107: e 48-52$.

9. Lise DP, Vieira LC, Araújo É, Lopes GC. Tooth fragment reattachment: the natural restoration. Oper Dent 2012;37:584-90.

10. Chosack A, Eidelman E. Rehabilation of a fractured incisor using the patient's natural crown-case report. J Dent Child 1964;71:19-21.

11. Reis A, Francci C, Loguercio AD, Carrilho MR, Rodriques Filho LE. Re-attachment of anterior fractured teeth: fracture strength using different techniques. Oper Dent 2001;26:287-94.

12. Farik B, Munksgaard EC, Andreasen JO. Impact strength of teeth restored by fragment-bonding. Endod Dent Traumatol 2000;16:151-3.

13. Pusman E, Cehreli ZC, Altay N, Unver B, Saracbasi O, Ozgun G. Fracture resistance of tooth fragment reattachment: effects of different preparation techniques and adhesive materials. Dent Traumatol 2010;26:9-15.

14. Rajput A, Ataide I, Lambor R, Monteiro J, Tar M, Wadhawan N. In vitro study comparing fracture strength recovery of teeth restored with three esthetic bonding materials using different techniques.
Eur J Esthet Dent 2010;5:398-411.

15. Maia EA, Baratieri LN, de Andrada MA, Monteiro S Jr, de Araújo EM Jr. Tooth fragment reattachment: fundamentals of the technique and two case reports. Quintessence Int 2003;34:99-107.

16. Capp CI, Roda MI, Tamaki R, Castanho GM, Camargo MA, de Cara AA. Reattachment of rehydrated dental fragment using two techniques. Dent Traumatol 2009;25:95-9.

17. Toshiriro K, Rintaro T. Rehydration of crown fragment 1 year after reattachment: a case report. Dent Traumatol 2005;21:297-300.

18. Farik B, Musksgaard EC, Andreasen JO, Kreiborg S. Drying and rewetting anterior crown fragments prior to bonding. Endod Dent Traumatol 1999;15:113-6.

19. Robertson A, Andreasen FM, Bergenholtz G, Andreasen JO, Munksgaard C. Pulp reactions to restoration of experimentally induced crown fractures. J Dent 1998;26:409-16.

20. Li Z, Cao L, Fan M, Xu Q. Direct pulp capping with calcium hydroxide or mineral trioxide aggregate: a meta-analysis. J Endod 2015;41:1412-7. 


\section{상악 전치부 치관 파절의 보존적이고 심미적인 접근법: 파절편 재부착}

\section{정경화 ${ }^{1,2}$, 권은영 ${ }^{1}$, 김소연 ${ }^{1}$ 전혜미 ${ }^{1}$, 손성애 ${ }^{2}$, 박정길 $^{2 *}$}

${ }^{1}$ 부산대학교병원 치과진료센터

${ }^{2}$ 부산대학교 치의학전문대학원 치과보존과학교실

치관 파절은 영구치, 특히 치열에서 가장 노출된 위치에 존재하는 상악 전치에 가장 많이 발생하는 외상성 손상이다. 파 절편 조각이 존재하고 상태가 양호한 경우 치관 파절을 치료하는 방법 중 하나는 원래 위치에 다시 파절편을 재부착하는 것이다. 이번 연구에서는 상악 전치에 발생한 치관 파절 증례를 파절편 재부착 술식으로 치료하였으며 심미적, 기능적으 로 만족할만한 결과를 얻었기에 이를 보고하는 바이다.

(구강회복응용과학지 2019;35(2): 105-12)

주요어: 치관 파절; 파절편 재부착; 심미적 접근; 보존적 접근 